\title{
Reliability and validity test of the Korean version of Noe's evaluation
}

\author{
Yedam Ho, Oh Young Kwon, So Youn Park, Tai Young Yoon and Young-eun Kim \\ Department of Medical Education and Medical Humanities, Kyung Hee University School of Medicine, Seoul, \\ Korea
}

Purpose: This study aims to demonstrate whether the functionalities between the widely used questionnaire in other countries and the Korean-translated version show similarity. Also, it intends to verify their reliability and validity.

Methods: The original questionnaire was first developed by professor Noe at the University of Minnesota with 29 items named as "mentoring functions" to identify the participants' psychological and career-development functions. Using the Korean-translated version of the original questionnaire, the study was conducted on total 288 Kyung Hee University medical students, ranging from the first-year students to the third-year students on December 2015. In order to investigate if the survey form could be applied to the Korean participants, exploratory factor analysis and confirmatory factor analysis were conducted, using varimax rotation. Cronbach $\alpha$ statistics and the figures of standardized regression weights were analyzed respectively to indicate construct, convergent, and discriminant validities.

Results: The result of exploratory factor analysis shows there are a total of three functions, including the additional "friendship function" (Eigen value, 1.152; significant level if higher than 1.0) with its high emphasis. The result of confirmatory factor analysis also demonstrates the similarity $(p=0.000)$. As the whole reliability scale of the three functions is significantly high (Cronbach $\alpha$, 0.971), each reliability scales of the three functions are shown to be high $(0.814-0.955)$ as well.

Conclusion: The model, with its three functions, proved the significant statistics regarding the reliability and validity. According to this ground, the conclusion is that the adapted questionnaire used in this study could be applied to Korean medical students.

Key Words: Mentoring, Reproducibility of results, Medical students

\section{Introduction}

Medical students are under significant pressure because they not only have to master their major studies and practical techniques, but also set their career paths and look for jobs at the same time. According to the study [1], although medical students have various problems with their academics and career paths, it is shown that $67 \%$ of them do not find any colleagues or professors who can provide sincere advice and feedback. Thus, their burdens in the academics and futures are cumulative.

According to a study [2] conducted in the United States, most medical schools have mentoring programs (79\%) or advising programs (100\%). To follow this trend,
Received: July 4, 2016 • Revised: October 5, 2016 • Accepted: December 8, 2016 Corresponding Author: Oh Young Kwon (http://orcid.org/0000-0003-0817-2256) Department of Medical Education and Medical Humanities, Kyung Hee University School of Medicine, 26 Kyungheedae-ro, Dongdaemun-gu, Seoul 02447, Korea

Tel: +82.2.961.9102 Fax:+82.2.969.6958 email: koy04@naver.com
Korean J Med Educ 2017 Mar; 29(1): 15-26.

https://doi.org/10.3946/kjme.2017.49

eISSN: 2005-7288

(C) The Korean Society of Medical Education. All rights reserved. This is an open-access article distributed under the terms of the Creative Commons Attribution Non-Commercial License (http:// creativecommons.org/licenses/by-nc/3.0/), which permits unrestricted non-commercial use, distribution, and reproduction in any medium, provided the original work is properly cited. 
Korean medical schools are adopting similar mentoring programs.

In mentoring programs, mentors are defined as doctors and medical professors who are relatively experts in their fields, and mentees are medical students who are less experienced. Mentoring is a series of activities [3] where mentors pass down their tips and know-how to their mentees and encourage them. Therefore, mentoring includes interactions between mentors and mentees, and it eventually brings positive effects for both of them. Concretely, it is expected that mentors [4] can help their mentees develop teamwork, communication, and personalrelationship skills through mentoring programs. Also, mentees can not only decide their career paths more wisely, but also reduce their pressure by sharing their personal issues with their mentors. Particularly, medical students can develop a deep understanding of a doctor as a professional job and strengthen their network through mentoring systems, because in large part, the mentees follow the same career directions as their doctor mentors did. With mentoring programs, both mentors and mentees can maintain their networks and develop their career even after graduation. Due to these benefits, accepting mentoring programs in many Korean medical schools is a rising trend.

However, there is a lack of development for valid measurements in order to prove its effectiveness and its domestic application. Therefore, developing appropriate measuring systems is significant and necessary to accumulate empirical research for the mentoring field. For these reasons, this study intends to develop an adapted Korean-version questionnaire, which [5] was originally created by professor Noe at the University of Minnesota in 1988. Finally, the purpose of this study is to establish a foothold to afford better mentoring programs to Korean medical students.

\section{Subjects and methods}

\section{Subjects}

The participants of this study were current Kyung Hee University medical students in their first, second, and third years. Of 288 total students, except those who responded falsely (four students) and did not respond, there were 174 male students and 114 females.

\section{Measurement tool}

The questionnaire that professor Noe created in 1988 at the University of Minnesota is composed of 29 items. However, this study was conducted with the Korean version (Appendix 1). All the items were measured using a 5-point Likert-type scale ranging from 1 (strongly disagree) to 5 (strongly agree). The original questionnaire was used after receiving prior consent from Professor Noe by email. Each item corresponds to an individual function, but the overall functions are largely divided into psychosocial (15 items) and career development functions (14 items). This classification of the functions is cited from the classification of mentoring functions [6], by Kathy Kram at Boston University. According to the classification of the original questionnaire, the psychosocial functions include acceptance and confirmation, role model, counseling and friendship, whereas the career development functions include coaching, protection, exposure and visibility, sponsorship, and challenging assignments. The survey questionnaire was provided as supplementary material to this article.

\section{Methods}

The sample estimation process should be conducted robustly in order to enhance the quality of studies. Larger samples are superior to smaller samples in many 
ways. Researchers can minimize the probability of committing errors, increase the generalizability of their findings, and maximize the accuracy of their conclusion through employing larger samples. According to researchers, 10 cases for each item should be sufficient to perform an exploratory factor analysis [7]. This study has a sufficient number of subjects with a total of 288 valid subjects.

This study used the Kaiser-Meyer-Olkin (KMO) test and Bartlett's test of sphericity to measure the adequacy of samples in terms of the distribution of values for the execution of factor analysis. Exploratory factor analysis was used to examine whether the application of the adapted questionnaire to the Korean medical students can correspond to the same categorization of these functions. In the exploratory factor analysis, the principal factor method and the varimax method were used. This study conducted the confirmatory factor analysis to examine the model validity of the factors that are tied to the same group from the exploratory factor analysis. Also, since it is important to retain the reliability and validity in the confirmatory factor analysis, Cronbach $\alpha$ statistic was calculated and construct, convergent, and discriminant validity were conducted. The confirmatory factor analysis was performed with the use of chi-square, root mean square error of approximation (RMSEA) and comparative fit index to examine the fitness and correspondence of the model as a whole. Standard regression weights were used for the construct validity. The convergent validity was examined by using the construct reliability and variance extracted index. The discriminant validity was examined by using coefficient of determination and variance extracted index. This study used SPSS version 21.0 (IBM Corp., Armonk, USA) and Amos 20.0 (IBM Corp.), respectively, and the significance level was set for 0.05 .

\section{Results}

\section{General characteristics of the participants}

The participants of this study were composed of $60.4 \%$ male students and $39.6 \%$ of female students. The number of people in each year is as follows (Table 1).

\section{Result of exploratory factor analysis}

In this study, the KMO test and Bartlett's test of sphericity were used to measure the adequacy of the collected samples prior to the execution of exploratory for its suitability in the factor analysis. The outcome for the KMO test was 0.963 , so the conformity was confirmed to perform the factor analysis. Also, as the stage to figure out common factors and to indicate the suitability of the factor analysis model, Bartlett's test of sphericity generated 7,490.33 (0.000), showing the statistical significance. Since the variables are correlated with each other, this study can use the principal factor method. According to these grounds, the principal factor method, which uses varimax rotation, was performed as the factor extraction method. The table of the rotational component matrix is shown in the Table 2. The factor analysis was conducted with the principal component analysis using of varimax rotation to group common factors within 29 items. The result of the exploratory factor analysis within the 29 items of the original

Table 1. Demographic Characteristics of the Samples $(n=288)$

\begin{tabular}{lr}
\hline \multicolumn{1}{c}{ Characteristic } & No. $(\%)$ \\
\hline Gender & \\
Male & $174(60.4)$ \\
Female & $114(39.6)$ \\
Grade & \\
1 & $90(31.2)$ \\
2 & $101(35.1)$ \\
3 & $97(33.7)$ \\
\hline
\end{tabular}


Table 2. The Result of Factor Structure

\begin{tabular}{|c|c|c|c|c|}
\hline Item & $\begin{array}{c}\text { Factor } 1 \\
\text { (psychosocial function) }\end{array}$ & $\begin{array}{c}\text { Factor } 2 \\
\text { (career development function) }\end{array}$ & $\begin{array}{c}\text { Factor } 3 \\
\text { (friendship function) }\end{array}$ & Cronbach a \\
\hline n 8 & 0.779 & & & 0.955 \\
\hline n 5 & 0.769 & & & \\
\hline n 6 & 0.738 & & & \\
\hline n 1 & 0.717 & & & \\
\hline n 12 & 0.715 & & & \\
\hline n 7 & 0.712 & & & \\
\hline n 2 & 0.712 & & & \\
\hline n 10 & 0.674 & & & \\
\hline n 9 & 0.666 & & & \\
\hline n 3 & 0.661 & & & \\
\hline n 14 & 0.650 & & & \\
\hline n 4 & 0.644 & & & \\
\hline n 13 & 0.620 & & & \\
\hline n 15 & 0.582 & & & \\
\hline n 18 & & 0.824 & & 0.954 \\
\hline n 19 & & 0.812 & & \\
\hline n 21 & & 0.792 & & \\
\hline n 17 & & 0.753 & & \\
\hline n 16 & & 0.723 & & \\
\hline n 24 & & 0.704 & & \\
\hline n 20 & & 0.698 & & \\
\hline n 23 & & 0.670 & & \\
\hline n 25 & & 0.643 & & \\
\hline n 11 & & 0.629 & & \\
\hline n 26 & & 0.610 & & \\
\hline n 22 & & 0.540 & & \\
\hline n 29 & & & 0.744 & 0.814 \\
\hline n 27 & & & 0.680 & \\
\hline n 28 & & & 0.510 & \\
\hline Eigen value & 16.357 & 2.159 & 1.152 & \\
\hline Kaiser-Meyer-Olkin & & & & 0.963 \\
\hline \multicolumn{5}{|c|}{ Bartlett' test of sphericity } \\
\hline Chi-square & & & & $7,490.33$ \\
\hline df (p-value) & & & & $406(0.000)$ \\
\hline
\end{tabular}

df: Degree of freedom.

questionnaire was different from the result of this Korean version research form. The original questionnaire was classified into two parts: psychosocial and career development functions.

However, this new study showed different outcomes; "friendship functions" was added. As a result, the researchers of this study decided to group the 12 items except two items in "psychosocial functions," because the items were originally in the same category. With regard to the factor 2, the 12 items except one item were overlapped with the original questionnaire, so we decided to call them "career development functions" as the original ones are named. The last three items were classified as "friendship functions" in the original questionnaire as sub-functions. Therefore, we emphasize "friendship functions" as new functions of this study. The

18 Korean J Med Educ 2017 Mar; 29(1): 15-26. 
total explanation power of the three factors was $67.819 \%$ and each Eigen values were higher than 1.0 (Table 2).

\section{Result of confirmatory factor analysis}

Previously, through the exploratory factor analysis, we determined that the two categories the original research form proposed were inappropriate in South Korea. Accordingly, the confirmatory factor analysis was performed to examine the suitability of the three factor structures of the mentoring program functions that were discovered in the exploratory factor analysis. The fit index obtained in the confirmatory factor analysis is shown in the Table 3. The result of the structure equation analysis showed chi-square statistics, the degree of freedom (df), and p-value. Generally, goodness of fit is interpreted as statistically significant if $\mathrm{p}$-value is higher than 0.05 and $\mathrm{p}$-value gets higher when the statistics of chi-square gets smaller. The probability of the statistics of chi-square also increases when the size of samples gets higher. In other words,

Table 3. Structure Model Fit Indices

\begin{tabular}{lccccccc}
\hline & df & \multirow{2}{*}{$\chi^{2}$} & p-value & \multirow{2}{*}{ CFI } & RMSEA & \multicolumn{2}{c}{ RMSEA (90\% CI) } \\
\cline { 7 - 10 } & & & & & & LO & HI \\
\hline Factor model & 406 & $7,490.33$ & 0.000 & 0.853 & 0.101 & 0.095 & 0.106 \\
\hline
\end{tabular}

df: Degree of freedom, CFI: Comparative fit index, RMSEA: Root mean square error of approximation, LO: Lower limit, HI: Upper limit.

Fig. 1. Three-Factor Model of Mentoring Function

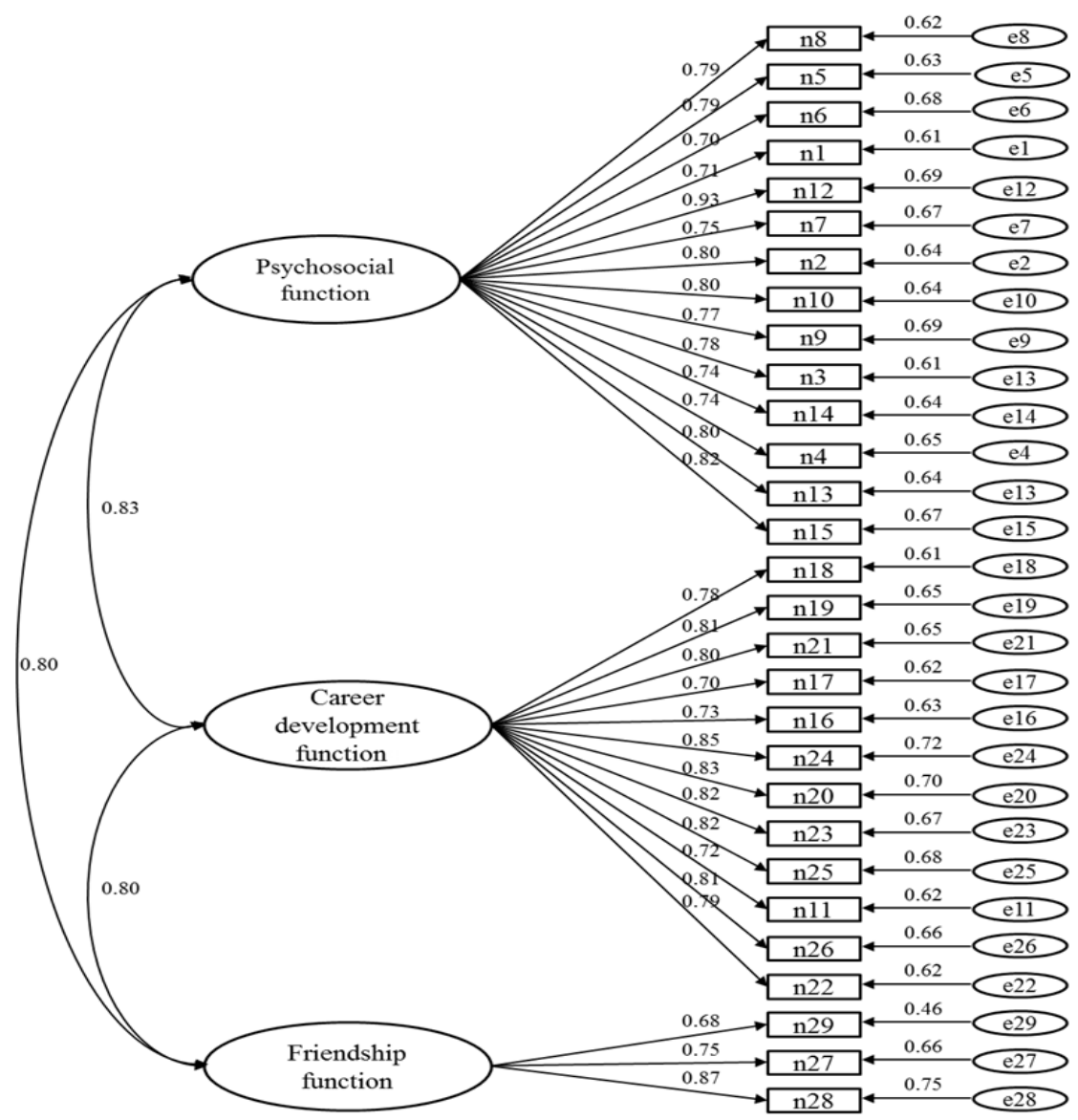


since the $\mathrm{p}$-value is influenced by the chi-square and the size of samples, it cannot be said that the goodness of fit is lower in a situation where the size of samples is high and the data with many variables [8]. Therefore, it is important to make a decision regarding the goodness of fit with other various indexes.

There is RMSEA that is not affected by the size of samples. RMSEA is statistics that equals chi-square adjusted by using $\mathrm{df}$ and size of sample. Mostly, if RMSEA is lower than 0.08 , it demonstrates that the goodness of fit is considerably high. Especially, within a 90\% confidence interval, it demonstrates higher goodness of fit [9] when the upper value is lower than 0.08. The confirmatory factor analysis in this research demonstrated a favorable RMSEA (0.101), showing in 0.095 to 0.106 range in the $90 \%$ confidence interval. Also the confirmatory factor analysis demonstrated a reasonable comparative fit index as 0.853 . A standard coefficient estimation shown in Fig. 1 demonstrates statistical significant in the level of significance 0.05. Standard coefficient estimation of the sub-function of three factors indicated 0.80 to 0.83 .

\section{Result of reliability analysis}

Cronbach $\alpha$ (Table 4) regarding the 29 items and the three factors were calculated to examine the reliability that measured the mentoring programs. As a result of the internal consistency of the scales, Cronbach $\alpha$ statistics for the factor 1, 2, and 3 were $0.955,0.954$, and 0.814, respectively. The overall Cronbach $\alpha$ statistic including all the 29 items is 0.971 , demonstrated competent level of the reliability.

\section{Result of validity analysis}

Construct validity was secured because standardized regression weights (Table 5) in all items were higher than 0.5. Construct reliability (Table 6) was confirmed because the internal consistency of the observed variables was higher than 0.7. Convergent validity was retained since all variance extracted indices was higher than 0.5. Regarding discriminant validity, a comparison of variance extracted indices (Table 6) and coefficients of determination (Table 7) shows that three of them are higher

Table 4. Reliability of Factors

\begin{tabular}{lc}
\hline \multicolumn{1}{c}{ Factor } & Cronbach $\alpha$ \\
\hline Total & 0.971 \\
Factor 1 (psychosocial function) & 0.955 \\
Factor 2 (career development function) & 0.954 \\
Factor 3 (friendship function) & 0.814 \\
\hline
\end{tabular}

Table 5. Standardized Regression Weights Regarding the Three Factors

\begin{tabular}{clc}
\hline Item & Factor & Estimate \\
\hline n 8 & Factor 1 & 0.790 \\
n 5 & Factor 1 & 0.794 \\
n 6 & Factor 1 & 0.763 \\
n 1 & Factor 1 & 0.712 \\
n 12 & Factor 1 & 0.829 \\
n 7 & Factor 1 & 0.753 \\
n 2 & Factor 1 & 0.799 \\
n 10 & Factor 1 & 0.800 \\
n 9 & Factor 1 & 0.765 \\
n 3 & Factor 1 & 0.783 \\
n 14 & Factor 1 & 0.738 \\
n 4 & Factor 1 & 0.744 \\
n 13 & Factor 1 & 0.801 \\
n 15 & Factor 1 & 0.821 \\
n 18 & Factor 2 & 0.779 \\
n 19 & Factor 2 & 0.805 \\
n 21 & Factor 2 & 0.804 \\
n 17 & Factor 2 & 0.790 \\
n 16 & Factor 2 & 0.729 \\
n 24 & Factor 2 & 0.850 \\
n 20 & Factor 2 & 0.834 \\
n 23 & Factor 2 & 0.821 \\
n 25 & Factor 2 & 0.824 \\
n 11 & Factor 2 & 0.722 \\
n 26 & Factor 2 & 0.815 \\
n 22 & Factor 2 & 0.787 \\
n 29 & Factor 3 & 0.677 \\
n 27 & Factor 3 & 0.746 \\
n 28 & Factor 3 & 0.869 \\
\hline & &
\end{tabular}


Table 6. Construct Reliability and Variance Extracted Index

\begin{tabular}{lcc}
\hline \multicolumn{1}{c}{ Factor } & Construct reliability & Variance extracted index \\
\hline Psychosocial function & 0.952 & 0.657 \\
Career development function & 0.971 & 0.702 \\
Friendship function & 0.812 & 0.592 \\
\hline
\end{tabular}

Table 7. Coefficient of Determination among the Factors

\begin{tabular}{lc}
\hline \multicolumn{1}{c}{ Factor } & Coefficient of determination \\
\hline Factor 1 \& Factor 2 & 0.689 \\
Factor 2 \& Factor 3 & 0.640 \\
Factor 1 \& Factor 3 & 0.640 \\
\hline
\end{tabular}

and three of them are lower, therefore it secured partial discriminant validity.

\section{Discussion}

The original Noe's questionnaire "Mentoring Functions Item" consisted of 29 total items. Although the questionnaire was created in 1988, a lot of research $[10,11]$ has been performed continuously based on this survey form. In various countries, other studies $[12,13,14,15]$ investigating the function of mentoring programs have been published as well.

The questionnaire used in this study has been used widely in abroad and its validity has been proved. Also, a lot of research conducted in companies or schools in Korea have proven its validity. However, that was not the case for Korean medical students. Therefore, it was necessary to prove if the questionnaire can be applied to medical students. According to the results of factor analysis, the mentoring functions of Kram [6], which Noe quoted, were originally classified into two functions. However, we discovered a total of three functions with an emphasis on the friendship functions through our research conducted on Korean medical students. The order of Cronbach $\alpha$ statistics is as follows from the highest to the lowest: psychosocial functions (0.955), career development functions (0.954), and the friendship functions (0.814). This indicates that the overall reliability is high.

Thus, this adapted questionnaire used in this study is suitable for Korean students to measure the satisfaction of the mentoring programs. According to the study conducted in the United States [16], Noe's questionnaire is the most frequently used questionnaire for evaluating mentoring programs, and it examines two functions ${ }^{-}$ psychosocial functions and career development functions.

Kram [6] classified psychosocial and career development functions as the main functions of the mentoring programs. However, since then, many non-Korean studies propose that highly emphasized "role model functions" should be the third functions. After Kram classified the mentoring functions into two parts, many follow-up researchers [5] have maintained the same point of views. However, the study conducted by Scandura [17] added the "role model functions," resulting in total three functions. This result shows some differences, because this study emphasizes "friendship functions," not the role model functions.

The reliability and validity of each tri-functional questionnaires reach beyond satisfactory level. We have come to the conclusion that the research form can be applied to Korean medical students for the reason mentioned above. It is widely known that medical students are under so much pressure [18] because of the heavy workload, long period of study, and the pass/fail 
system. The fact that mentoring programs can be helpful for the medical students $[19,20]$ has been proved through research. Considering the specific circumstances of medical school, it is important to develop measurement tools for Korean medical students to implement qualified mentoring programs.

This study confronts two limitations as follows. First, bilingual participants in Korean and English are ideal for comparing the original and the adapted questionnaire, but this study is far from that ideal process. The reason is that the researchers think it will give extra burden to medical students, who struggle with heavy workload although the students were bilingual. Second, the participants of the study are chosen only from Kyung Hee University, not from other universities. Due to the specific characteristics of mentoring programs that only Kyung Hee University possess, it is necessary to collect extra samples from other universities. In spite of these limitations, this study holds a significant meaning in that it provides an opportunity to adopt Korean version questionnaire about mentoring programs which are widely used in various countries. The purpose of the study is achieved sufficiently, since it proves its high reliability and validity in different aspects.

Through this study, we want to make two proposals. First, to secure the criterion-related validity of the study, it is necessary to use other studies with different measurement tools as criteria. This study cannot prove the criterion-related validity, due to the fact that there are no Korean measurement tools in which the reliability and validity have been qualified. Hence, the development of the measurement tools for mentoring programs should be implemented in follow-up studies. Second, this study is focused only on medical students. However, considering that interest in mentoring programs for residents and faculty members is increasing [21], measurement tools for mentoring programs for these people in follow-up studies should be developed.

In conclusion, the questionnaire used in this study proves its reliability and validity. Therefore, we are looking forward to applying this adapted questionnaire to other Korean medical schools regarding the research of mentoring programs.

ORCID: Yedam Ho: http://orcid.org/0000-0001-6171-7476; Oh Young Kwon: http://orcid.org/0000-0003-0817-2256; So Youn Park: http://orcid.org/0000-0003-0553-5381;

Tai Young Yoon: http://orcid.org/0000-0002-5743-9044; Young-eun Kim: http://orcid.org/0000-0003-0694-6844

Acknowledgements: None.

Funding: None.

Conflicts of interest: None.

\section{References}

1. Shin HI, Jeon WT. "I'm not happy, but I don't care": help-seeking behavior, academic difficulties, and happiness. Korean J Med Educ 2011; 23: 7-14.

2. Fornari A, Murray TS, Menzin AW, Woo VA, Clifton M, Lombardi M, Shelov S. Mentoring program design and implementation in new medical schools. Med Educ Online 2014; 19: 24570.

3. Sanfey H, Hollands C, Gantt NL. Strategies for building an effective mentoring relationship. Am J Surg 2013; 206: 714-718.

4. Bae J, Ahn J, Pang J. The growth and challenges in mentoring participation: focused on students' evaluation of KBU SMILE mentoring program. Soc Work Pract Res 2014; 11: 95-144.

5. Noe RA. An investigation of the determinants of successful assigned mentoring relationships. Pers Psychol 1988; 41: 457-479. 
6. Kram KE. Phases of the mentor relationship. Acad Manag J 1983; 26: 608-625.

7. Nunnally JC. Psychometric theory. 2nd ed. New York, USA: McGraw-Hill; 1978.

8. Joo YJ, Kim NY, Cho HK. Test development and verifying the validity and reliability for measuring a effectiveness of e-learning course in cyber university. J Korean Assoc Inf Educ 2008; 12: 109-120.

9. Lee HS, Rhim JH. Structural equation modeling with AMOS 6.0. Seoul, Korea: Bobmunsa; 2007. p 32-35.

10. Son SJ, Kuchinke KP. The moderating role of trust in formal mentoring relationships in Korea. Asia Pac J Hum Resour 2016; 54: 57-58.

11. Ono K, Kato K. Succession of the mentor role and the experience of proteges among Japanese workers. Paper presented at: Annual Meeting of the International Society for the Systems Sciences; 2003 July 6; Crete, Greece.

12. Fowler JL, O'Gorman JG. Mentoring functions: a contemporary view of the perceptions of mentees and mentors. Br J Manag 2005; 16: 51-57.

13. Özkalp E, Kirel Ç, Sungur Z, Cengiz AA. Mentoring revisited from the perspective of mentors in learning process: the case study of Anadolu University in Turkey. Paper presented at: University Forum for Human Resource Development; 2006 May 31; Tilburg, Netherlands.

14. Kaderli R, Muff B, Stefenelli U, Businger A. Female surgeons' mentoring experiences and success in an academic career in Switzerland. Swiss Med Wkly 2011; 141: w13233.

15. Gong R, Chen SY, Lee SL. Does mentoring work? The mediating effect of mentoring in China. Soc Behav Pers 2011; 39: 807-824.

16. Allen TD, Eby LT, O'Brien KE, Lentz E. The state of mentoring research: a qualitative review of current research methods and future research implications. J Vocat Behav 2008; 73: 343-357.

17. Scandura TA. Mentorship and career mobility: an empirical investigation. J Organ Behav 1992; 13: 169-174.

18. Ramanan RA, Phillips RS, Davis RB, Silen W, Reede JY. Mentoring in medicine: keys to satisfaction. Am J Med 2002; 112: 336-341.

19. Frei E, Stamm M, Buddeberg-Fischer B. Mentoring programs for medical students: a review of the PubMed literature 2000-2008. BMC Med Educ 2010; 10: 32.

20. Sambunjak D, Straus SE, Marusic A. A systematic review of qualitative research on the meaning and characteristics of mentoring in academic medicine. J Gen Intern Med 2010; 25: 72-78.

21. Chen MM, Sandborg CI, Hudgins L, Sanford R, Bachrach LK. A multifaceted mentoring program for junior faculty in academic pediatrics. Teach Learn Med 2016; 28: 320-328. 
Appendix 1. Survey on Mentoring Program

안녕하십니까?

본 설문지는 "의학전문대학원/의과대학 학생들의 멘토링 프로그램 만족도 수준에 관한 연구"를 위한 것으로, 의학전문대학원/의과 대학 학생들이 현재 참여하고 있는 멘토링 프로그램에 대한 만족도 수준을 파악하고 개선점을 찾아보고자 합니다. 의학교육학교실은 귀하의 응답내용을 익명으로 처리하여 연구목적으로만 사용할 것을 약속드립니다. 귀하의 설문과 본 연구가 경희대학교 의학전문대학 원/의과대학 내 교육프로그램의 개선에 있어 큰 도움이 될 것입니다.

설문지상의 질문을 읽으신 뒤 귀하께서 생각하거나 느끼시는 척도를 선택하여 표시해주시기 바랍니다. 설문 소요 시간은 약 5 분이며 모든 질문에 빠짐없이 응답해 주시기를 부탁드립니다.

연구의 내용이나 질문항목과 관련하여 궁금하거나 제언해 주실 사항이 있으신 분은 아래 연락처로 문의해주시기 바랍니다. 의학전문 대학원 학생들의 적극적인 참여 부탁드립니다.

대단히 감사합니다.

\section{5년 12월}

경희대학교 의학교육학교실 (의과대학 404호)

연구책임자: 권오영

공동연구원: 호예담

[서명지]

본인은 연구참여 설명서를 통해 본 연구에 대한 목적 및 기대효과, 진행과정, 연구대상자의 권리 등 모든 필요한 정보들에 관하여 연구책임자로부터 자세하게 설명을 듣고 충분히 이해하였습니다.

본인은 언제라도 연구에 대한 궁금한 점이나 정보에 대해 연구책임자에게 문의할 수 있음을 알고 있으며, 언제라도 연구 참여 의사를 철회할 수 있음을 알고 있습니다.

본인이 제공하는 모든 정보는 기밀이 유지되며 연구 목적으로만 사용될 것을 이해합니다.

본인은 저의 개인정보에 대하여 현행법의 범위 내에서 연구자가 수집하고 처리하는 데에 동의합니다.

본인은 연구자나 그의 대리인 또는 기관위원회나 감독기관이 조사를 하는 경우 비밀로 유지되는 개인정보를 열람하는 데에 동의합니다.

이에 본인은 자유로운 의사에 따라 본 연구에 참여할 것에 동의하며, 이에 동의서에 서명하고, 동의 후에 필요 시에 동의서 사본을 제공받을 수 있음을 알고 있습니다.
연구참여자:
성명
(서명)
서명일: 2015년 12월 일 
1. 다음 항목에 대해 귀하가 해당되는 곳에 체크(v) 바랍니다.

\begin{tabular}{|c|c|c|c|c|}
\hline 1 & 성별 & (2) 여 & & \\
\hline 2 & 학년 & (1) 1학년 (2) 2학년 (3) 3학년 & (4) 4학년 (5) 의예과 1학년 & \\
\hline 3 & 동료 멘티 수 (본인 제외) & (2) 1 명 & (4) 3 명 (5) 4 명 & \\
\hline 4 & 멘토-멘티 모임 횟수 & (1) 월 1회 이상 & (3) 6개월에 1회 & (5) 모임 거의 없음 \\
\hline 5 & 멘토-멘티 모임 평균 소요 시간 & (1) 1시간 이내 & (3) 3 시간 이상 & \\
\hline 6 & 멘토-멘티 모임 장소 & (1) 교수연구실 & (3) 교수자택 (4) 기타 & \\
\hline 7 & 멘토-멘티 대화의 주된 주제 & (1) 학습상담 & (3) 생활상담 (4) 1-4번 모두 & \\
\hline
\end{tabular}

2. 다음은 귀하가 속한 경희대학교 의학전문대학원/의과대학 학생들을 대상으로 시행하고 있는 멘토링 프로그램에 관한 질문입니다. 해당되는 란에 체크(v)해 주시기 바랍니다.

\begin{tabular}{|c|c|c|c|c|c|}
\hline 설문내용 & $\begin{array}{l}\text { 전혀 } \\
\text { 그렇지 } \\
\text { 않다 }\end{array}$ & $\begin{array}{l}\text { 그렇지 } \\
\text { 않다 }\end{array}$ & $\begin{array}{l}\text { 보통 } \\
\text { 이다 }\end{array}$ & 그렇다 & $\begin{array}{c}\text { 매우 } \\
\text { 그렇다 }\end{array}$ \\
\hline
\end{tabular}

1 나의 멘토교수는 자신의 경험을 당신과 공유한다.

2 나의 멘토교수는 당신이 성장할 수 있도록 독려해준다.

3 나의 멘토교수는 내가 일이나 공부를 할 때 어떻게 행동해야 하는지 알려주고 독려해 준다.

4 나는 나의 멘토교수의 직업적 행동을 모방하려고 노력한다.

5 나는 나의 멘토교수의 교육에 관한 태도와 가치에 동의한다.

6 나는 나의 멘토교수를 존경하고 인정한다.

7 나는 나의 멘토교수와 비슷한 위치가 된다면 내 멘토교수처럼 되기 위해 노력할 것이다.

8 나의 멘토교수는 나의 말을 잘 들어준다.

9 나의 멘토교수는 나의 능력, 나의 발전, 동료, 교수나 가족들의 관계에 대해서도 대화하려고 한다.

10 나의 멘토교수는 내 문제들을 해결하기 위해 개인적인 경험을 공유한다.

11 나의 멘토교수는 나의 가치를 손상시키는 걱정이나 불안을 공개적으로 이야기하도록 독려해준다.

12 나의 멘토교수는 함께 이야기한 걱정이나 고민에 대해 공감해준다.

13 나의 멘토교수는 나와 나누었던 비밀을 잘 기억해주고 있다.

14 나의 멘토교수는 나를 개인적으로 존중해준다.

15 나의 멘토교수는 내가 중요한 결정을 할 때 생기는 불필요한 위험요소를 줄여준다.

16 나의 멘토교수는 내가 과제를 마감 시한에 맞게 낼 수 있도록 도와준다.

17 나의 멘토교수는 내가 새로운 동료들을 만나는 것을 도와준다.

18 나의 멘토교수는 학교 행정실과 개인적인 접촉할 수 있도록 도움을 준다예: 장학금 신청 등).

19 나의 멘토교수는 나의 성장 잠재력을 판단할만한 사람들과 접촉할 수 있게 해준다.

20 나의 멘토교수는 진로 준비를 할 수 있도록 해준다.

21 나의 멘토교수는 내가 새로운 기술을 습득할 수 있는 기회를 제공한다.

22 나의 멘토교수는 교육자로서 내 능력에 관해 피드백을 주거나 도와준다.

23 나의 멘토교수는 나의 직업적 목표 달성을 위한 전략을 제시해 준다.

24 나의 멘토교수는 나와 함께 아이디어를 공유한다. 
Yedam Ho, et al: Reliability and validity test of the Korean version of Noe's evaluation

25 나의 멘토교수는 나의 학업적 목표 달성을 위한 전략을 제시해 준다.

26 나의 멘토교수는 현재 나의 일과 관련된 성과에 대한 피드백을 제공해 준다.

27 나는 멘토교수와 함께 식사를 종종 하곤 한다.

28 나의 멘토교수는 당신이 학교에서 접하는 문제들에 대해 제안을 해준다.

29 나의 멘토교수와 나는 학교나 병원 이외의 장소에서 만난다.

설문에 응답해 주셔서 진심으로 감사드립니다. 